\title{
HANNAH ARENDT: O QUERER E A LIBERDADE
}

\author{
Carlos Antonio Mendes de Carvalho \\ Buenos Ayres (UnB) \\ menayres@ig.com.br
}

Resumo: o artigo propõe-se a descrever, segundo o crivo analítico de Hannah Arendt, o percurso histórico-teórico que conduz ao aparecimento de uma das três faculdades do espírito: a faculdade da vontade ou querer. Remontando inicialmente à Grécia antiga, logo empreende um movimento progressivo até a nossa contemporaneidade, segundo a contribuição de pensadores clássicos, medievais e modernos. Numa visão retrospectiva, Arendt discorre com acuidade acerca do processo de percepção e assunção da faculdade da vontade, correlacionando-o com o advento e consolidação da concepção linear do tempo, de extração cristã, em contraposição à concepção cíclica do tempo, de extração helênica. Também discorre sobre o embate que se instala entre a faculdade do querer e o pensar, através da polêmica entre São Tomas de Aquino e Duns Scotus. Por fim, o artigo aproxima a faculdade da vontade à noção de liberdade, fundamento da condição humana.

Palavras-chave: a faculdade da vontade, a faculdade do pensar, a liberdade.

\section{INTRODUÇÃO}

Perscrutar com acuidade o pensamento de um autor qualquer já se constitui por si só uma tarefa ingente. Imaginem quando a tarefa que se nos impõe a "vontade" é esquadrinhar o pensamento de uma autora de grande estatura intelectual, cujo escopo é rastrear as faculdades do espírito, a saber, o Pen- 
samento, a Vontade e o Julgar, tais como elas são suscitadas nos cérebros de uma plêiade de filósofos e teólogos notáveis. A autora à qual nos referimos é Hannah Arendt, que, com uma erudição enciclopédica, procura dar conta da trajetória dessas faculdades do espírito, num empreendimento que infelizmente não chegou a seu termo devido ao seu passamento. Longe de nós, no entanto, enveredar pelo caminho que nos conduzem a fazer o mesmo; só que desta vez guiado pelo travejamento seguro, mas nem por isso mais fácil, produzido pela autora em apreço. Por isso, nos debruçaremos apenas sobre uma das faculdades do espírito que reputamos ser estratégico na compreensão de seu pensamento e de suas intenções explicativas contidas em sua obra: a faculdade da Vontade. Mas para isso traçamos um itinerário que nos parece ser dotado de uma lógica histórico-cronológica e cognitiva. No primeiro tópico, portanto, que é o mais longo, nos preocuparemos em fazer um "sensoriamento remoto" que nos permita identificar o momento da "descoberta" da faculdade da Vontade entre os filósofos medievais; as razões que a alçaram à condição de primun inter pares no âmbito das demais faculdades do espírito, entre os filósofos da Era Moderna; as desconfianças dos filósofos pós-medievais quanto à sua existência; assim como apresentar as justificativas da autora em apreço acerca do porquê do seu não conhecimento por parte dos filósofos da Antigüidade Grega. No segundo tópico, procuraremos identificar os caracteres de duas das principais faculdades do espírito, a saber, do Pensamento e da Vontade, e também considerações acerca do conflito entre eles. No terceiro e último tópico, ensaiaremos alguns incipientes passos na direção de uma sucinta, modesta e temerária tentativa de interpretação do pensamento de uma das mais discutidas pensadoras desse final de século, que se transmuda também em final de milênio. 


\section{O ADVENTO DA VONTADE ENQUANTO FACULDADE DO EsPíRITO}

Segundo Hannah Arendt, a Vontade, enquanto faculdade autônoma e distinta do espírito, era de todo desconhecida na Antigüidade Grega, sendo que seu "descobrimento" decorreu de experiências que só tomamos conhecimento a partir do século I da Era Cristã. Arendt relata que a maior das dificuldades com que ela se defrontou em suas análises sobre a Vontade, foi o fato de que essa, entre todas as faculdades do espírito, teve sua existência posta em dúvida, tida como "ilusão da consciência, sendo a mais contestada de todas por uma plêiade de conspícuos filósofos e teólogos, tais como Gilbert Ryle (a vontade não passa de um "conceito artificial"); e isso parece derivar de um conflito entre as experiências obtidas pelo ego pensante e aquelas obtidas pelo ego volitivo.

O ponto de partida de Arendt, em sua busca para precisar o instante cronológico da descoberta da Vontade e de seu trajeto histórico, é a seguinte indagação: De que modo a filosofia grega tratou de questões relativas aos fenômenos e dados da experiência do homem? Hannah recorre a Aristóteles, a quem reconhece como precursor da Vontade. Segundo ela, Aristóteles parte do insight antiplatônico segundo o qual a razão, em si mesma, nada pode fazer ou mover, e o que norteia as suas reflexões é a questão "O que é que, na alma, origina o movimento?”. Em Aristóteles, a razão dá ordens, mas não tem garantia de que tais ordens sejam cumpridas; e, ao admitir que o homem incontinente deixa-se conduzir por seus desejos à revelia da razão, embora esta possa influir na resistência aos objetos desse desejo, ela termina por chegar a alguma coisa. Porém, nem os próprios desejos por si mesmos possuem força capaz de originar movimento, não obstante gozar de prerrogativa na deflagração destes - trata-se de um jogo cujos participantes são 
a razão e o desejo. É a "ação" de desejar algo que não está presente é que induz ao aparecimento da razão, pois é a razão que pondera acerca dos meios mais apropriados para atingir o objeto desejado. Mas Hannah adverte que o próprio Aristóteles considerou como insuficiente a inter-relação da razão com o desejo na explicação da ação humana, uma vez que "(...) ela se baseia ainda, embora com modificações, na dicotomia platônica entre razão e desejo" (ARENDT, p. 299, 1993). Para resolver esse impasse ou superar tal dicotomia, Aristóteles cunha um termo que expressa um estado espiritual que precede a ação: a proairesis (faculdade da escolha), que se traduz por uma escolha entre duas opções, entre duas possibilidades (a preferência entre estudar ou não estudar, trabalhar ou não trabalhar, à guisa de exemplos). Assim, a escolha termina por se constituir na força propulsora das ações ou, como esclarece HANNAH, “(...) é uma faculdade intermediária, inserida por assim dizer, na dicotomia mais antiga entre razão e desejo; e sua principal função é mediar a relação entre os dois" (ibidem, p. 231). Por isso ela diz que a proairesis de Aristóteles, ou seja, a faculdade da escolha constitui-se como precursora da Vontade.

Dando continuidade ao desvelar histórico com relação ao período cronológico que antecede ao surgimento ou descoberta da Vontade, Hannah observa que Aristóteles sedimentou o terreno no qual a filosofia seria conduzida ao advento da Vontade. Isso ocorre, segundo Hannah, devido às concepções de Aristóteles quanto à contingência dos acontecimentos em oposição ao ser dos entes - "(...) aquilo que necessariamente é como é, que é e não pode não ser" (ibidem, p. 197); e das atividades humanas, através das quais tudo o que é produzido ou fabricado pelo homem tenha de antemão uma existência que pré-existe à sua feitura no mundo das coisas aparentes - no espírito do produtor ou fabricante, ou seja, tudo o que 
o homem produz, muito antes de tê-lo produzido, já existe potencialmente em seu espírito, do mesmo modo que a semente encerra potencialmente em si própria a existência do carvalho, assim como o sêmen encerra, in potentia, o animal, seja ele racional ou irracional - a coisa produzida provém de algo que em si mesmo, previamente, conserva potencialmente o resultado terminante.

A acuidade intelectual de Arendt, secundada por sua erudição um tanto quanto enciclopédica, capta que aí reside o nó górdio das razões pelas quais Aristóteles não poderia ter chegado à descoberta da faculdade da Vontade como faculdade independente e autônoma - tudo aquilo que a configuração da proairesis não comporta -, além, é claro, como veremos mais adiante, da própria noção temporal fundada na circularidade dos acontecimentos, em que estes tendem recorrentemente a repetirem-se ad infinitum. É o que podemos depreender das palavras de ARENDT:

A visão de que tudo o que é real deve ser precedido de uma potencialidade como uma de suas causas nega implicitamente o futuro como um tempo verbal autêntico: o futuro nada mais é que uma conseqüência do passado, e a diferença entre as coisas naturais e as feitas pelos homens reside simplesmente na distinção entre aquelas cujas potencialidades necessariamente transformam-se em atualidades e aquelas que podem ou não se atualizar. Nessas circunstâncias, qualquer idéia da Vontade como órgão para o futuro, do mesmo modo que a memória é um órgão para o passado, era completamente supérflua; Aristóteles não precisava ter consciência da existência da vontade (...). (ibidem, p. 198)

Hannah Arendt acrescenta, recorrendo a Gilbert Ryle, que o fato de que Platão e Aristóteles não tenham feito qualquer alusão a volições em suas discussões acerca da "natureza da alma e origens da conduta" - e, conseqüentemente, a impossi- 
bilidade da tese segundo a qual o problema da liberdade tenha despertado a atenção tanto de Sócrates quanto de Platão e Aristóteles - é compatível com a concepção de tempo da Antigüidade (os falsi circuli dos pagãos, na expressão de Santo Agostinho) - a concepção circular ou cíclica do tempo, observada no movimento dos planetas e na vida terrena (o ciclo de nascimento e vida, noite e dia); e Hannah ARENDT complementa,

Quando Aristóteles sustenta que 'vir-a-ser' necessariamente implica a preexistência de algo que é em potência, mas não em ato" (sic), ele está aplicando ao campo dos assuntos humanos o movimento cíclico que afeta tudo o que vive - em que de fato todo fim é um começo e todo começo um fim, de maneira que o 'vir-a-ser continue, embora as coisas estejam constantemente sendo destruídas': (ibidem. 199)

Hannah percebe que o surgimento histórico do conceito cíclico do tempo resulta de uma conseqüência lógica associada à noção de perenidade do ser, que nunca nasceu embora exista, mas que nunca poderia fenecer e cuja asseidade é eterna, de natureza incriada. Portanto, era natural que os filósofos esclarecessem, tendo por base tal concepção, "o ir e vir dos seres vivos". Daí o fato de que Hannah infere que é natural que os gregos fossem impossibilitados de se acercar do conhecimento da faculdade da Vontade, cujo vetor é o futuro (que é portador de uma incerteza básica e, ao mesmo tempo, é promotor do novo), conduzindo, conseqüentemente, ao abismo da liberdade e o subseqüente estabelecimento de uma "nova ordem das eras", como veremos no último tópico.

Mas no decorrer do desenvolvimento da filosofia cristã, o conceito cíclico do tempo foi paulatinamente substituído pelo conceito de linearidade. Foi a essa altura que a Vontade foi reconhecida como uma faculdade autônoma do espírito. Mas como isso se dá? Hannah lembra que a compreensão da 
história passa a ter um novo referencial cujo ponto zero é a expulsão de Adão do paraíso, passando pela morte e ressurreição de Cristo - trata-se de uma história permeada de acontecimentos que não mais se repetem. De fato, tais acontecimentos não se repetem, no entanto seus efeitos ainda perduram no tempo e possuem uma realidade histórica que ainda é eficaz, fluindo junto com o tempo: o acontecimento Jesus Cristo. Logo, se se trata de uma história seqüenciada, onde há um início e um fim definidos - a parusia de Cristo como ponto culminante e terminante -, então o conceito de tempo adequado é o retilíneo. Hannah completa dizendo que, para o cristão, a vida após a morte dependia de sua conduta pregressa na terra, e que São Paulo foi o primeiro a descobrir a Vontade e a liberdade que lhe é inerente, graças a essa preocupação terrena para com um futuro situado no além-vida. Porém, em São Paulo, a descoberta da Vontade é experimentada como um imperativo que se traduzia em submissão voluntária (a experiência do "eu-queroe-não-posso"); a Vontade é impotente porque ela constitui um obstáculo para si própria.

Resumindo, Hannah Arendt observa que toda vez que defrontamos, nas discussões da Idade Média, com a faculdade da escolha (equivalente ao liberum arbitrium, da língua latina) segundo Aristóteles, não estamos tratando com um poder espontâneo de engendrar alguma coisa nova, muito menos com uma faculdade autônoma autosubsistente e em conformidade com leis que lhe são orgânicas. Portanto, a Vontade enquanto faculdade autônoma só é descoberta a partir do momento em que os homens fizeram o seguinte questionamento: "As coisas que só a mim dizem respeito estão em meu poder?"; a coincidência entre o "tu-deves" e o "eu-posso" (ibidem, p. 233).

Em seu itinerário analítico, às voltas com a estrutura da Vontade no âmbito da história da filosofia, Hannah também 
discorre detidamente sobre as concepções de Epiteto, Santo Agostinho, São Tomás de Aquino, Duns Scotus, entre os filósofos e teólogos medievais, e, sobretudo, Hegel, Nietzsche e Heidegger, entre os filósofos da Era Moderna.

Ao referir-se a Epiteto, Arendt observa que ele também, a exemplo de Aristóteles, consente com o insight de que a razão, compreendida em si mesma, nada realiza ou move, pois cabe à Vontade, que é soberana e "livre da escravidão e jugo", a realização das coisas que estão ao alcance do homem, ou seja, este só pode querer o que é possível de se obter e abster-se de não querer aquilo que é inevitável; e quando o poder da Vontade está em harmonia com as "coisas", 'querendo' apenas o que é, então, a Vontade torna-se onipotente. Desse modo, a razão apenas instrui a Vontade quanto às coisas que estão em poder do homem e as que não estão. As faculdades da Razão e da Vontade foram dadas ao homem porque este não possui nenhum poder sobre as coisas pertinentes ao mundo das aparências. Logo, tais faculdades capacitam o homem a reproduzir em seu espírito as coisas do mundo real. Uma vez reproduzido no espírito um mundo copiado da realidade, portanto um mundo não real em termos objetivos, dele o homem se assenhoreia onde apenas a Vontade pode constituir um entrave de si própria; o mundo real termina não sendo mais do que o produto do consentimento do ego pensante; sua realidade depende de minha aquiescência quanto à sua existência real. Tal é a compreensão da Vontade em Epiteto, segundo os estudos exaustivos de Hannah, e que constitui o centro de sua filosofia - "a arte de viver a própria vida". Para conseguir viver uma boa vida é fundamental "deixar a vontade ser tal que os eventos devam acontecer como acontecem” (apud ARENDT, p. 246, 1993) - a onipotência da Vontade. Em suma, para Epiteto, a onipotência da Vontade funda-se em duas pressuposições, 
conforme expõe Arendt: 1) a de que a realidade das coisas no mundo das aparências, depende do consentimento que atribuímos a ele, sem o qual ele não existiria para nós, e a recusa em conferir-lhe realidade constitui fator de seu evanescimento; 2 ) e como resultante desse último, a de que podemos dar cabo de nossas vidas se as condições em que vivemos tornarem-se insuportáveis - apenas a Vontade pode ser um óbice para si própria.

Arendt lembra que, a princípio, Santo Agostinho - a quem considera o "primeiro filósofo da Vontade" - se interessa pela faculdade da Vontade quando associada às indagações acerca da causa do mal, advertindo que a existência do mal pressupõe um fator causal que lhe antecede, e que Deus não pode ser tal fator causal porque "Deus é bom". Sua filosofia da Vontade apoia-se numa interpretação particular da Epístola de São Paulo aos Romanos. Ao contrário deste último, Santo Agostinho não se refere a duas leis, mas a duas vontades, a carnal e a espiritual. Baseado em suas próprias experiências, descreve o embate que ocorre entre tais vontades, ressaltando que querer e poder não são uma mesma realidade, embora estejam intimamente associadas - o poder não pode ausentar-se, senão a Vontade dele não pode dispor e utilizar; a Vontade não pode ausentar-se, senão o poder torna-se improdutivo. Para ele, a Vontade é livre, contrastando com a razão e mesmo com os desejos. Assim, na esteira do raciocínio de Santo Agostinho, segundo a interpretação que Hannah faz dele, a razão em si mesma pode me fornecer as ponderações para que eu me furte a deixar-me seduzir pelo objeto (externo) de meu desejo; ela pode forçar-me a abster da satisfação concreta de um tal desejo, mas não pode impedir-me de a ele responder positivamente - impedir-me de praticar o adultério, que é um dos exemplos dados por Santo Agostinho. Porém, a Vontade pode conduzir- 
me à resistência, porque ela é livre. Esta é, segundo Hannah, a prova da liberdade da Vontade, cuja plausibilidade decorre do cotejo feito acima entre Vontade e razão, entre Vontade e desejo, baseando-se unicamente numa "força interna de afirmação e negação". Desse modo, todo e qualquer ato da Vontade pressupõe a implicação do querer e do não querer.

Hannah explica que a própria experiência de Santo Agostinho, ao desencadear uma peleja consigo mesmo imediatamente anterior à sua conversão (metanoia), lhe possibilita subsídios suficientes para que ele reputasse como equivocado o conflito entre carne e espírito, no nível do dois-em-um de São Paulo. Se o espírito dá uma ordem ao corpo, esse obedece incontinenti, já que não tem vontade própria; mas se o espírito dá uma ordem a si mesmo, ele resiste. Nesse caso, a resolução do problema apresentado por Santo Agostinho situa-se no âmbito da própria Vontade, que se cinde. O conflito não resulta de uma cisão entre espírito e Vontade ou entre carne e espírito. Parte do próprio ego volitivo a ordem para querer ou para não-querer. A Vontade divide-se em duas vontades que se opõem - vontade e contra-vontade -, condição básica para que se consiga ter vontade. Nenhuma delas, no entanto, é completa, posto que sejam complementares - "(...) o que falta a uma está presente na outra” (apud ARENDT, 1993, p. 255). Portanto, a solução encontrada por Santo Agostinho para resolver esse conflito interno da Vontade, provém de uma transmutação no cerne da própria Vontade, que a transmuta em Amor - a Vontade final e unificadora que arbitra sobre o comportamento do homem é, portanto, o Amor, "uma espécie de vontade duradoura e livre de conflitos" (ibidem, p. 262).

São Tomás de Aquino e Duns Scotus duelam conceitualmente através da intrincada argumentação de Hannah Arendt; tanto que eles integram as discussões contidas num capítulo 
inteiro de sua obra Vida do Espírito - a peleja entre o Querer e o Intelecto. Comecemos pelas reflexões filosóficas de São Tomás, cuja argumentação se apoiava em enunciados de pensadores reconhecidos como autoridade nos assuntos por eles tratados, diferentemente de Santo Agostinho, que nunca recorria à opinião de terceiros, pois elaborava seus argumentos exclusivamente com base em suas próprias experiências. Para os escolásticos, "a experiência em si não inspira o argumento", e quando dela se utilizava era apenas no intuito de fundamentar seus próprios argumentos.

Segundo Arendt, São Tomás classifica a necessidade segundo três tipos: a necessidade absoluta (racional), a necessidade relativa (utilitarista) e a coerção. A coerção, que se opõe à verdade, também é imposta por um agente situado externamente. Enquanto a verdade, oriunda da necessidade absoluta, compele, mas não ordena. A vontade, oriunda da necessidade relativa, ordena, mas não coage. São Tomás distingue ainda dois tipos de faculdades de "apreensão": o intelecto e a razão. A cada uma dessas faculdades de apreensão corresponde uma das "faculdades intelectualmente apetitivas", a saber, respectivamente, vontade e livre escolha. Tanto o intelecto ("razão universal") quanto a razão ("razão particular") tratam de questões relativas à verdade. Se o intelecto, que é de natureza contemplativa, trata de questões relativas à verdade matemática ou axiomas, a razão é operacionalizada na medida em que extraímos conclusões específicas a partir de proposições universais, como é o caso dos silogismos. No intelecto, a verdade revela-se espontaneamente ao espírito; no raciocínio discursivo, o espírito é compelido por si próprio.

Quanto à Vontade, São Tomás postula que ela constitui uma categoria meios-fim, e o fim enquanto objeto da Vontade é concedido à Vontade mediante o intelecto - "Dá-se primeiro 
a apreensão do fim..., depois o conselho (deliberação) sobre os meios; e finalmente o desejo pelos meios" (apud ARENDT 1993, p.274). Trata-se da primazia do Intelecto enquanto faculdade de apreensão, sobre a Vontade enquanto faculdade ou movimento apetitivo. Arendt observa que a base conceitual de tais distinções é de que Bem e Ser são uma mesma realidade, diferindo apenas no nível do pensamento, e o mal não sendo não mais do que "privação", ou seja, "nenhum ser, na medida em que é pode ser dito mal, "mas somente à medida que lhe falte Ser'” (apud ARENDT, ibidem, p. 274). Visto pelo lado do Intelecto, o Ser transparece como verdade; visto pelo lado da Vontade, o Ser transparece como alguma coisa desejável, que o próprio Ser não consegue expressar.

Após tecer os comentários acima, a autora volta-se para o cerne da questão inicialmente proposta, isto é, a relação entre Intelecto e Vontade, e os argumentos de São Tomás acerca do primado do primeiro em relação ao segundo. Ao discorrer sobre o cotejo entre estas duas potências do espírito no sentido de verificar qual deles é "absolutamente mais alto e mais nobre”, Hannah Arendt assinala que num primeiro momento essa questão parece denotar certa confusão, pois o Ser, no que tange à Vontade, transparece como bom e desejável e, no que tange ao Intelecto, transparece como verdadeiro - "ambas as faculdades têm o mesmo objetivo final" (ARENDT, 1993, p. 274). E ela observa que São Tomás concorda com essa afirmação, quando defende que Intelecto e Vontade "estão incluídos um no outro em seus atos, porque o Intelecto entende que a Vontade quer, e a Vontade quer que o Intelecto entenda" (apud ARENDT, 1993, p. 276); logo, para São Tomás, se o universal é "mais nobre e ocupa posição mais alta" o cotejo entre Intelecto e Vontade, sob o ponto de vista da "universalidade de seus respectivos objetos", demonstra a primazia do Intelecto sobre a 
Vontade. Porém, tal primazia não reside tanto na relação entre seus respectivos objetos, ou seja, a primazia da Verdade sobre o Bem, e sim na maneira a partir da qual estas duas potências espirituais competem no interior do espírito humano. Como afirma São Tomás, toda e qualquer ação da Vontade pressupõe uma compreensão, mas a compreensão não pressupõe uma ação da Vontade; só se pode querer o que se conhece.

A autora afirma ainda que a principal razão pela qual São Tomás postula a primazia do Intelecto em relação à Vontade está diretamente associada à resposta à indagação sobre o "fim e a felicidade última do homem": "A felicidade última do homem é essencialmente conhecer Deus pelo Intelecto; não é um ato da Vontade" (apud ARENDT, ibidem, p.278). Mas adverte para o fato de que a concepção de São Tomás acerca das faculdades apetitivas deriva da idéia de se desejar usufruir de algo fora desta vida que nela mesma não pode ser satisfeita, e que o Intelecto só garante sua primazia em relação à Vontade não apenas porque "apresenta um objeto ao apetite" e que lhe antecede, mas igualmente devido ao fato de que sobrevive à extinção da Vontade no próprio momento em que essa atinge o objeto.

Com relação a Duns Scotus, Arendt observa que ele, a exemplo de São Tomás, é pródigo nas referências às opiniões de autoridades da Antigüidade e no emprego da razão argumentativa. No entanto, a contrapelo de São Tomás, para quem a Vontade constitui um órgão executivo inteiramente subserviente ao Intelecto, Scotus considera o Intelecto como faculdade espiritual a serviço da Vontade, sendo que a funcionalidade daquele (Intelecto) depende dessa (Vontade) não só para dirigir sua atenção, mas também para confirmar o seu objeto - é o primado da Vontade.

Mas que postulado subsiste no núcleo da reflexão e misericórdia de Duns Scotus? Hannah responde que se trata da 
convicção inabalável de que o homem, uma vez inserido numa ordem contingente e por mais culto e genial que seja, jamais poderia conhecer algo recorrendo à razão natural. Segundo Scotus, só existe uma faculdade que faz com que o homem transcenda a sua finitude absoluta: a Vontade. Como afirma ARENDT (p. 283, 1993), interpretando o pensamento de Scotus, "é a possibilidade de resistência às necessidades do desejo, por um lado, e aos ditames do intelecto e da razão, por outro, que constituem a liberdade humana. Mas a independência da Vontade com relação à asseidade (hecceidade) das coisas deparase com uma única limitação, que é a impossibilidade de negar a totalidade do Ser -“(...) a qualidade básica de nossa vontade é que podemos querer ou não-querer o objeto apresentado pela razão ou pelo desejo"(ibidem, p. 283). E, embora a autonomia da Vontade limite o poder da razão, ela não pode limitar o poder da natureza, seja a "natureza do homem interior", seja a "natureza das circunstâncias exteriores".

A autora mostra que, em Scotus, encontram-se dois tipos distintos de vontade: a vontade natural, que se orienta pelas inclinações naturais podendo ser inspirada tanto pela razão quanto pelo desejo; a vontade livre propriamente dita que indica os fins que são perseguidos livremente por si mesmos. Subjacente a essas distinções e que constitui a essência de seu pensamento, Arendt indica a doutrina da Contingência ("o preço pago de bom grado pela liberdade”) que, para Scotus, não indica “(...) algo que não é necessário ou que não tivesse sempre existido, mas sim algo cujo oposto poderia ter ocorrido no momento em que esse realmente ocorreu. É por isso que não digo que uma coisa é contingente, mas sim que é causada contingentemente" (apud ARENDT, p. 289, 1993). Ou, como simplifica Arendt, a realidade dos assuntos humanos é condenada à contingência e à imprevisibilidade devido à coincidência de uma pluralidade de causas. 
Hannah ainda observa que o problema da liberdade está estreitamente associado à doutrina da contingência, uma vez que tal problema decorre da própria faculdade da vontade, e que, subjacente ao fato da indeterminação da vontade humana (não se pode fazer ao mesmo tempo duas coisas que são contrárias, como, por exemplo, dormir e não-dormir), Scotus distingue a atividade pura - tem seu fim e ergon em si mesma - e a fabricação - "produzir ou moldar algum objeto externo". A fabricação desses objetos externos ou artefatos é uma atividade provisória, ao passo que as atividades do espírito (pensar, querer, julgar) não são transitórias, pois são atividades de primeira espécie. Mas se a vontade não é transitória (usufrui de si própria sem deixar de existir), o mesmo não acontece com o desejo (o prazer do desejo em obter algo leva à extinção do prazer e do desejo mediante a posse do objeto desejado).

Em suma, para Scotus, a liberdade da Vontade tem por objeto uma disposição de espírito espontânea e livre, podendo amar ou odiar, afirmar ou negar a Deus - "é essa liberdade da vontade de tomar uma posição espiritualmente que coloca o homem à parte do resto da criação; sem isso ele seria um animal esclarecido (bonum animal), na melhor das hipóteses ou (...) uma bestia intellectualis, uma besta intelectual" (grifo original) (ARENDT, 1993, p.287-288). E que, no contexto da distinção que faz entre Vontade e desejo, a harmonia entre eles, ou seja, a harmonia do dois-em-um só se dá quando a própria Vontade se transforma em amor; um amor duplamente concebido: não apenas depurado de desejos e necessidades, como também um 'veículo' a partir do qual a Vontade enquanto faculdade do espírito transforma-se em atividade pura.

Quanto a Nietzsche, esse "mestre da suspeita", Arendt explica que as suas concepções sobre a Vontade - fundadas em "experiências do pensamento" - têm por objeto o fato de que, 
no processo operacional da Vontade inerente a nosso espírito, a dualidade espiritual do dois-em-um é superada pela identificação do "Eu", em sua totalidade, com a parte comandada, ou seja, a coexistência entre o "Eu" que comanda, que ordena e que triunfa, e o "Eu" que é comandado, que obedece, apesar da resistência - a "liberdade da Vontade". Nietzsche empreende, portanto, a mudança do "eu-quero" para o "eu-posso" antecipado, cujo fundamento é a elevação da Vida à condição de summum bonum. Assim, para Nietzsche, o impulso que temos para exaltar a vida coincide com a nossa compulsiva vontade de querer - "a não querer, o homem prefere ainda querer o nada" (apud ARENDT, 1993, p. 310). Hannah acrescenta ainda que a característica principal da noção do "eterno retorno" empregada por Nietzsche e de seu método experimental de pensamento - e que não consiste nem em uma teoria, doutrina e tampouco numa hipótese - é que tal procedimento experimental de pensamento é incompatível com qualquer que seja o conceito de Vontade. Isso decorre, segundo Hannah, do fato de que os projetos da Vontade têm como condition sine qua non de sua existência, enquanto faculdade do espírito, a noção de linearidade temporal aliado à incognoscibilidade do futuro, que em si mesmo comporta a contingência dos eventos.

Arendt apresenta três enunciados descritivos de Nietzsche que a seu ver são por demais importantes:

1. A Vontade revela-se impotente quando se vê impossibilitada em querer algo que já não é; não pode agir retroativamente; não pode conter o processo de vir-aser do tempo, em função da irreversibilidade deste;

2. A noção de vontade-de-potência em si mesma desvela uma forma volitiva excessiva, uma vez que "o ato de poder em si já é um ato de potência”. Existe uma contradição básica no modus operandis do pensamento 
nietzscheano: a contradição entre um querer que é refratário ao que já não é (seu querer não retroage no tempo) e o ato de potência que expressa a própria Vontade (o "sentimento de força" ou "'indicação de força”).

3. A Vontade transcende a gratuidade do mundo, ou seja, supera-lhe em virtude da superabundância de vida, pois o que a Vontade almeja é a abundância, o sentimento excessivo de força.

Por fim, Arendt identifica nos experimentos, aforismos e observações contidos na obra póstuma Vontade-de-Potência, de Nietszche, um nítido repúdio tanto à Vontade quando ao ego volitivo, onde as experiências interiores deste último permitiram aos "homens pensantes" conceberem o equívoco em admitir na realidade das coisas, relações de causa e efeito, uma intenção manifesta e uma meta, cujo vetor é a perspectiva de alcance de um estado final.

Ao tratar do pensamento heideggeriano com relação à faculdade da Vontade e sua noção de querer-não-querer, Hannah destaca que a produção filosófica de Heidegger sofre uma guinada abrupta que ela chama de "reviravolta" (kehre). Hannah observa que é a partir da eclosão desta que se pode constatar que a sua concepção de Vontade passa a contrastar com a noção de vontade-de-potência, elemento característico de sua fase anterior e que está contido em sua obra, Nietzsche.

Arendt explica que, se antes da reviravolta Heidegger orienta-se em conformidade com as descrições das características da Vontade contidas no pensamento nietzscheano que o leva a adotar o conceito de "diferença ontológica" (a diferenciação entre o Ser do Ser e o fato de ser dos seres), após o advento daquela, ele pondera grande parte de suas asserções anteriores 
com relação ao assunto sobredito. Se antes, para Heidegger, a vontade-de-potência significava a maneira a partir da qual tudo que é, realmente é, e a Vontade traduzia-se em mera função do processo vital, uma mera necessidade biológica, na fase posterior à reviravolta, ele realiza uma mudança de ênfase ao adotar uma concepção de Vontade no sentido de governar e dominar - "O poder existe somente à medida que ele mesmo aumente $e$ à medida que [a vontade-de-potência] comande este aumento (apud ARENDT, 1993, p. 319)." Pois a Vontade compele a si própria ao se auto-impor comandos; logo, a essência do poder é a vontade-de-potência, não mais a vida. A Vontade só pode adquirir e manter um estatuto de existência na medida em que esteja relacionada com o poder; e sua obsessiva projeção para o futuro, à qual conduz o homem ao olvidamento do passado, por sua vez conduz à destrutividade final de tudo o que é.

Fazendo uma incursão na obra Ser e Tempo, de Heidegger, a autora identifica três termos que, segundo ela, são centrais na compreensão da reviravolta heideggeriana, a saber: Cuidado - a maneira básica mediante a qual o homem exercita o interesse existencial por sua própria asseidade; Morte - passa a constituir uma "redoma" protetora da essência dos mortais, sendo que os mortais assim o são porque a condição de estar morto é indissociável de seu ser mais íntimo; Eu - expressa a resposta à questão da identidade essencial do homem ("Quem é o homem?") no lugar da questão "O que o homem é? Desse modo, o "Eu é o termo para a existência do homem em oposição a qualquer qualidade que ele possa ter (ARENDT, p. 323, 1993)"; manifesta-se na "voz da consciência" instando o homem ao retorno de sua vida cotidiana (em meio ao convívio com as "pessoas"), retorno ao qual a consciência revelase como culpa humana ("uma espécie de pecado original"), sendo que essa revelação se dá através de seu chamado. Assim, 
para Heidegger, essa noção de culpa é inerente à própria existência humana, uma vez que se trata de uma existência factual - ponto nodal de sua noção de culpa - em que o homem é culpado independentemente do fato de ter ou não ter feito alguma coisa que justificasse tal imputação de culpa.

Para completar e tornar mais esclarecedora a idéia de "chamado da consciência", é importante analisar dois pontos, conforme observa a autora. Primeiro, o chamado da consciência se estabelece na exigência da aceitação da culpa, da dívida primordial imposta ao homem, e tal aceitação supõe uma ação silenciosa de seu Eu autêntico no sentido de um "agir em sua dívida"; esse "agir em sua dívida" somente pode ocorrer e existir no pensamento isolado de si mesmo ("solipsismo existencial”), constituindo a única e exclusiva ação no âmago factual da história. Segundo, na noção de dívida primordial dada pela própria existência factual do homem, podem-se perceber indícios que conduzem à identificação que Heidegger faz entre pensar e agradecer. A realização do chamado da consciência reside na recuperação do Eu autêntico, individualizado, em seu retorno ao recôndito de si mesmo, ejetado para fora do espaço/tempo da duração histórica em que os eventos se processam na cotidianidade do homem. O eu é intimado a enfronhar-se no pensamento solitário; ao deparar-se com o Ser, protagoniza uma atitude de agradecimento.

Arendt ressalta que Heidegger compreende a fusão entre pensar e agir como a fusão entre sujeito e objeto, visando a dessubjetivação do Ego Cartesiano e como fusão das transmutações verificadas na "História do Ser", através do exercício do pensamento dos pensadores. Esta História do Ser, enquanto conceito personificado, dotado, portanto, de uma existência fantasmagórica, se faz carne, movimentando-se por trás da ação do homem, isto é, do pensador, pois é o pensador que 
transforma em ação o significado oculto do Ser - ele é o Eu autêntico, que não mais atende ao chamado da consciência, mas unicamente ao chamado do Ser, pois deixa de querer para, serenamente, "deixar-ser". Hannah esclarece também que a causa de tal mudança é uma dupla radicalização: radicalização da tensão entre pensar e querer e radicalização do conceito personificado. É a História do Ser (conceito personificado) que determina em que condições ou termos o homem tem que lhe responder: em termos de querer ou em termos de pensar. Portanto, a tensão entre querer e pensar é resolvida quando o eu autêntico não age mais em si mesmo e nem mais responde ao chamado da consciência; responde apenas, obedientemente, ao chamado do Ser, uma vez que deixa de querer para "deixarser" - é o querer-não-querer heideggeriano.

Hannah Arendt esclarece que, se a faculdade da Vontade era ignorada na Antigüidade Grega sendo 'descoberta' apenas na Idade Média, como acima aludimos, é na Era Moderna que ela é identificada como "órgão espiritual próprio para o futuro"; isso decorre da noção de progresso, que é inerente à modernidade cuja ênfase é a compulsiva preocupação com o futuro, que assume o sentido do que determinamos em conformidade com os projetos da Vontade, em detrimento do que de nós se acerca como um simples desdobramento inexorável do vir-a-ser - é aqui que a concepção linear do tempo atinge as suas conseqüências mais lógicas. No entanto, Hannah ressalta que as especulações medievais sobre o tema ainda faziam sentir seus efeitos no decorrer dos séculos XVI e XVII, uma vez que a faculdade da Vontade era alvo de desconfianças renitentes, sendo grandes as reservas em se atribuir ao homem poder sobre seu próprio destino, motivo pelo qual a substituição da Razão pela Vontade, esta como a faculdade espiritual "mais alta e mais nobre”, só ocorreu no último estágio da Era Moderna. 
Assim, Arendt enumera algumas objeções feitas por diversos filósofos pós-medievais contra a faculdade da Vontade, a saber:

1) A faculdade da Vontade ou do Querer é colocada sob suspeita de ser uma "mera ilusão", "um fantasma da consciência". Entre aqueles que encararam com reservas a faculdade do Querer, destacam-se Hobbes e Espinoza. Tanto um quanto o outro não nega a existência da Vontade em termos subjetivos, porém, em termos objetivos, rejeitam a noção de liberdade que lhe é inerente; a partir de suas concepções conclui-se que "(...) os homens são subjetivamente livres e objetivamente assujeitados" (ibidem, p. 204). O mesmo se dá com Shopenhauer, que, embora não ponha em dúvida a faculdade da Vontade, não admite que ela seja livre;

2) A ligação necessária e inexorável entre a faculdade da Vontade e a Liberdade constituiu fator importante para que a desconfiança se instalasse nos cérebros dos filósofos pós-medievais; e mesmo entre aqueles que Hannah acoima de voluntaristas, houve certa relutância em admitir a efetividade da Vontade. Afinal, como atesta Arendt (ibidem, P. 206), “(...) a pedra de toque de um ato livre (...) é que sempre sabemos que poderíamos ter deixado de fazer aquilo que de fato fizemos"; além do que um dos elementos distintivos da faculdade da Vontade é de que ela é dotada de uma liberdade incomparavelmente superior a do pensamento;

3) Em conseqüência dessa ilimitada superioridade da faculdade do querer em relação ao pensamento em termos do usufruto de graus de liberdade, sobretudo 
pelo fato de que no homem coexistem o ego volitivo e o ego pensante, os filósofos pró-ego pensante rejeitam a "maldição" da contingência, isto é, a idéia de que acontecimentos deflagrados por uma vontade livre pode perfeitamente deixar de ser realizado.

Com o advento da Era Moderna e sua ênfase na idéia do progresso com conseqüente preocupação com o futuro, os defensores do ego pensante foram expostos de modo radical à contingência dos assuntos humanos, onde a vontade livre dos homens é orientada por uma entidade fantasmagórica rumo a uma meta última - é a filosofia da história de Hegel. Arendt informa ainda que a idéia de progresso enquanto conceito personificado - a exemplo da "mão invisível" de Adam Smith, do "ardil da natureza" de Immanuel Kant, da "astúcia da razão" de Friedrich W. Hegel, o "materialismo dialético" de Karl Marx, da "história do ser" de Martin Heidegger - transformou-se no projeto da humanidade, movimentando-se por trás dos homens. Portanto, a propensão do espírito para o futuro faz com que a preocupação humana resvale da preocupação para com "objetos", para a preocupação para com os projetos, os projetos da Vontade. Se o progresso pressupõe a crença no crescente aperfeiçoamento da humanidade e no alcance de uma meta pré-definida, o órgão espiritual por excelência apropriado ao futuro e fonte de ação é a faculdade da Vontade, dotada de poderes para "começar espontaneamente uma série de coisas ou estados sucessivos" - na expressão de Kant recorrentemente citada por Arendt -, ou seja, dotada com poderes para deflagrar algo novo.

Hannah Arendt atribui a Hegel a façanha de ter sido o primeiro filósofo a elaborar uma filosofia da história. Para ele, a primazia do passado cede lugar à primazia do futuro, pois o espírito volta-se para o Devir, para o tempo do ainda-não, em 
que, uma vez chegando o Devir a seu termo, o ser realiza-se, passando a pertencer ao passado; a realização do ser coincide com a primazia do passado, e é através da Vontade que o tempo é produzido pelo espírito - “(...) o passado é produzido pelo futuro, e o pensamento, que contempla o passado, é o resultado da Vontade. Porque a vontade, em última instância, antecipa a frustração final dos projetos da vontade, que é a morte; tais projetos também um dia terão sido" (ibidem, p. 218).

Hannah faz uma ressalva importante. Hegel não obtém êxito em sua tentativa de apaziguar o conflito entre o pensar e o querer mediante a operação de noções temporais opostas. A sua noção de superação dialética (aufhebung), na qual as concepções temporais, cíclica e retilínea, são conciliadas, pressupõe um movimento progressivo, logo, linear cujo objetivo é o desdobramento do "Espírito do Mundo" encarnado na humanidade em que sucessivas gerações vão surgindo intermitentemente, expressando novas etapas existenciais que, por sua vez, se traduzem como recomeços elevados a um nível superior em relação aos que imediatamente lhe antecederam - cada novo fim é um novo começo. No desenrolar desse processo de superação dialético, tanto o ego pensante quanto o ego volitivo são prejudicados, uma vez que tal processo não tem como fundamento as experiências destes. Contudo, o caráter infinito desse processo se coaduna com os projetos do ego volitivo e sua preocupação com o futuro, agora com a concepção retilínea que lhe é inerente.

\section{EGO PENSANTE E EGO VOLITIVO}

Já nos referimos à suposição de Hannah Arendt com relação ao fato de que as desconfianças atribuídas à existência da faculdade da Vontade, decorreriam de um conflito entre as ex- 
periências tanto do ego pensante quanto do ego volitivo. O que importa agora é saber em que consiste e como se dá tal conflito.

Hannah explica que as atividades espirituais do ego pensante e do ego volitivo "parecem incapazes de coexistir", e que a oposição que entre eles se instaura termina por atingir os estados psíquicos que experimentamos, uma vez que um e outro fazem com que o que está ausente manifeste-se presentemente em nosso espírito, mas com uma diferença básica entre ambos. Enquanto o ego pensante (o Pensamento) transmuda em um agora duradouro, aquilo que é ou que já deixou de ser, ou seja, o que se passou, o ego volitivo (a Vontade), ao projetar-se para o futuro, penetra em um âmbito cuja principal característica é a incerteza. $\mathrm{O}$ ego pensante volta-se para o passado, e este, por sua vez, apresenta-se ao espírito sob o signo da certeza; o ego volitivo focaliza sua atenção no futuro, naquilo que não é senão uma mera eventualidade, mas que está em seu poder fazer com que essa mera eventualidade deixe, ela mesma, de ser uma mera eventualidade - o futuro na condição de um projeto da Vontade que rejeita o que o mundo das aparências oferece.

$\mathrm{O}$ humor que predomina no ego pensante, segundo Arendt, é a serenidade - atividade ligada intimamente à lembrança que não se opõe à resistência das coisas no mundo das aparências; tende a inclinar-se para a melancolia. $\mathrm{O}$ humor que predomina no ego volitivo é a tensão, a impaciência, a inquietude, a preocupação. Enquanto o Pensamento nada faz, é inoperante, a Vontade sempre almeja fazer alguma coisa, pois intervém no mundo das aparências visando a realização de seus projetos. Essa ação inquieta no mundo das aparências decorre da reação da alma ao futuro, que é mediado pela esperança e pelo medo, assim como pressupõe um eu-posso destituído de uma garantia absoluta - "A inquietação preocupada da Vontade só pode ser apaziguada por um 'eu-quero-e-faço', isto é, por 
uma interrupção de sua própria atividade" (ibidem, p. 214). A tensão que se verifica na faculdade da Vontade entre o querer algo em nosso alcance e a capacidade em dar uma resposta positiva a tal querer (a sua realização), uma vez que querer e poder realizar não coincidem, provoca uma inquietação, cuja solução se encontra no fazer, quando cessa toda atividade espiritual.

\section{ElEMENTOS PARA UMA INTERPRETAÇÃO DO PENSAMENTO AREN- DTIANO}

Hanna Arendt trabalha com desenvoltura suas incursões nos pensamentos de alguns dos principais teólogos e filósofos de todas as épocas; sua circunvolução às vezes é desconcertante, porque o seu pensamento não descreve uma trajetória linear sob o ponto de vista da construção discursiva literária - ele é tanto circular nas apresentações das suas nuanças constitutivas, no sentido da constante recorrência e antecipações a variantes do assunto de referência em apreciação, quanto no sentido da não consecução estratégica de uma resposta definitiva e absoluta às questões colocadas, cuja feição assume o caráter do ensaio. Assim, o seu procedimento argumentativo circunscreve um trajeto idêntico ao empreendido pelos grandes expoentes do pensamento escolástico, ou seja, apóia-se nas premissas filosóficas de tais autoridades não só para corroborar quanto para invalidar o alcance cognitivo das teses destes, em benefício de suas próprias posições pessoais, a exemplo de São Tomás de Aquino e Duns Scotus, para citarmos apenas estes.

Parece-me que o fio condutor do pensamento arendtiano é a idéia de que a Vontade enquanto faculdade autônoma do espírito é a única que possui não só o potencial, mas, também, o poder efetivo de induzir a ação humana rumo à realização do novo, pois a Vontade está irremediavelmente vinculada à idéia 
de liberdade; esta, por sua vez, constitui a capacidade que temos de iniciar algo inteiramente novo, uma nova série seqüencial no tempo, cuja efetividade poderia não ser concretizada.

Ora, é essa preocupação com a capacidade de começar algo novo que conduz e fundamenta o pensamento de Arendt, razão pela qual o edifício teórico produzido por ela revela um quadro compreensivo/explicativo onde as noções de princípio de causalidade plural, ação, liberdade, natalidade e morte são articuladas organicamente. Não é à toa que Hannah atribua tanta importância ao pensamento de Duns Scotus e a sua obstinada e vigorosa defesa da faculdade da Vontade enquanto faculdade "mais alta e mais nobre" do espírito, tendo o Intelecto como uma faculdade que lhe é subserviente. Afinal, dos filósofos e teólogos estudados por ela, apenas Duns Scotus estava disposto a arcar com o ônus da contingência em função da liberdade. Numa situação diametralmente oposta, encontram-se Nietzsche e Heidegger. Com relação a este último, nada é mais contrário à sua posição teórica do que a concepção heideggeriana do Querer-não-Querer, uma vez que o que tal concepção propugna é a abdicação do homem da liberdade de querer e poder fazer o que lhe aprouver, atendendo apenas aos seus ditames internos em função de sua consciência e moralidade, por um lado, e pela atividade cotidiana submetida ao princípio de causalidade, por outro; ao invés disso o homem somente atende ao chamado do Ser, deixando assim de querer para "deixar-ser" - a "História do ser", na condição de um conceito personificado e/ou uma entidade fantasmagórica, é quem guia a humanidade, pois constitui “(...) um Alguém que transforma em ação o significado oculto do Ser (...)" (grifo original) (ibidem, p. 326).

Segundo H. Arendt, parece ser estranho que a liberdade seja acalentada pela faculdade da Vontade. Na realidade, o pro- 
blema da liberdade é central para a compreensão do problema político, sendo que o seu aparecimento na tradição filosófica ocidental resultou primeiramente das experiências de conversão religiosa, originalmente em São Paulo, posteriormente em Santo Agostinho. Mas foi no âmbito político, como um fator factual da vida cotidiana, que a liberdade constituiu-se em um problema político. Ao contrário da noção primeva de liberdade desenvolvida pelos filósofos da Antigüidade, em que está associada ao exercício da Vontade e na relação que se dá na esfera do diálogo sem som comigo mesmo (o dois-em-um socrático), que também se transmuda em livre arbítrio, a noção de liberdade, enquanto concepção vinculada às questões políticas, constitui-se em um problema político que se caracteriza como um produto do agir humano no quadro da pluralidade coletiva da espécie humana. Em suma, focalizando sua atenção nos homens de ação, antes exaustivamente centrada nos filósofos, Arendt empreende um percurso argumentativo que vai da noção de liberdade filosófica à noção de liberdade política. Para ela, a liberdade filosófica (liberdade da Vontade) é de usufruto exclusivo dos indivíduos isolados ao largo das comunidades políticas e se traduz pela qualidade do eu-quero. Quanto à liberdade política, o seu exercício só pode realizar-se no interior das comunidades políticas, ou seja, na esfera da pluralidade humana e suas respectivas leis, uma vez que não é o homem em termos genéricos que a possui, mas o cidadão; ela expressa a qualidade do eu-posso. Desse modo, a realização empírica da liberdade dá-se apenas quando o ato de querer coincide com o ato de poder (eu quero e posso).

Como a própria Hannah reconhece, a liberdade política pressupõe a existência do "Nós" e seu engajamento na construção de algo novo no mundo. Daí a referência que ela faz às lendas fundadoras (romana, hebraica etc) como, por exemplo, 
a fundação de Roma cujo começo é, na realidade, um recomeço, pois não se tratava de um "começo absolutamente novo". Ocorre que, no que se refere à fundação, que é "o ato supremo pelo qual o "Nós" constitui-se como uma entidade identificável", a ação dos homens é motivada pelo amor à liberdade, que, por seu turno, pode ser duplamente expressa: como "liberação da opressão" e como "estabelecimento da Liberdade como realidade estável e tangível” (ibidem, p. 338). Conseqüentemente, um hiato instala-se entre o "desastre e a salvação", entre a "liberação da velha ordem e a nova liberdade", que é encarnada em uma novus ordo seclorum (uma nova ordem das eras) - "O hiato legendário entre um não-mais e um ainda-não indicava claramente que a liberdade não seria um resultado automático da liberação, que o fim do velho não é necessariamente o começo do novo, que a noção de um contínuo do tempo todo-poderoso é uma ilusão". Assim como adianta que, quando os homens de ação desenvolvem atividades voltadas para mudar o mundo, eles defrontam-se com o "abismo da liberdade", ou seja, a contingência de que o que quer que almejem fazer poderia deixar de ser feito e que uma vez feito, tal fato seria irreversível e resistiria ao arrependimento e à destruição graças à memória enquanto registro histórico.

Para H. Arendt, liberdade política é sinônimo de ação, pois é apenas no ato de agir que radica o processo de construção do mundo onde os homens vivem, sendo que ela é a razão pela qual eles convivem em comunidades politicamente organizadas; sem isso a vida política não teria significado - "A raison d'être da política é a liberdade, e seu domínio de experiência é a ação" (ARENDT, 1972, p. 192). Porém, a ação não se subordina nem ao Intelecto e nem à Vontade; ela deriva de um princípio inspirador cuja manifestação se faz através do ato de realização, de maneira que tal ato desencadeia um conjunto de 
conseqüências sob a forma de pluralidade causal, que, por sua vez, transforma-se em pluralidade de efeitos para, em seguida, transformar-se novamente em pluralidade causal, e assim sucessivamente. É por isso que Arendt postula que as atividades do labor (processo biológico associado ao corpo humano), do trabalho (processo artificial de produção das coisas) e da ação (atividade desenvolvida no seio da atividade humana ao largo da intermediação da matéria e das coisas), que ela denomina de Vita activa, estão intimamente associadas com a natalidade e a mortalidade, que consistem nas condições básicas gerais da existência humana. Porém, para ela, das três atividades acima referidas, a atividade da ação é a que se encontra mais estritamente vinculada com a condição humana da natalidade, como vimos há alguns parágrafos atrás, uma vez que cada novo começo deflagrado pelo nascimento é dotado da faculdade de encetar alguma coisa nova, ou seja, é dotado da faculdade da ação - ação e natalidade coincidem no pensamento de Hannah Arendt: "(...) como a ação é a atividade política por excelência, a natalidade, e não a mortalidade pode constituir a categoria central do pensamento político, em contraposição ao pensamento metafísico" (ARENDT, 1997, p.17).

\section{Conclusão}

O fôlego intelectual de Hannah Arendt não deve absolutamente ser julgado por esse sucinto e parcializado ensaio. Não nos preocupamos em fazer um julgamento de sua obra, o que seria uma pretensão descabida e um exercício de insipiência incomensurável, e tampouco de apresentar a sua versão de a "Vida do Espírito". Nosso insignificante conhecimento de sua grande produção teórica não nos autoriza a aventurar nos meandros de um pensamento um tanto irrequieto, que 
não se detém perante as dificuldades mais intransponíveis. $\mathrm{O}$ que fizemos foi sistematizar algumas questões relativas ao segundo volume da sobredita obra, a saber: "O Querer (A Vontade)". Em razão disso, procuramos demonstrar, com base nos argumentos da autora em consideração, que havia uma impossibilidade lógica que impedia os filósofos gregos, sobretudo Aristóteles, de ter descoberto a faculdade da Vontade enquanto potência autônoma e distinta do espírito; ao invés disso, a solução peripatética foi criar a expressão proairesis, que consiste no ato de escolha entre duas alternativas de conduta e que equivale ao termo latino liberum arbitrium, mas que não tem o poder espontâneo de iniciar algo novo e nem é dotada de autonomia, e, no entanto, é considerada por Arendt como a precursora da Vontade. Como os filósofos gregos só tinham uma percepção temporal fundada no movimento circular, ou seja, uma concepção temporal na qual os acontecimentos tendem à repetição ad infinitum - o mito do eterno retorno -, associada à idéia de existência potencial imediatamente anterior à existência concreta das coisas e à idéia de perenidade do Ser - além do fato de que a noção de liberdade entre eles sempre se referia à relação de livre deslocamento espacial -, o advento da Vontade era impossível, dada a sua preocupação para com o futuro. Graças às concepções filosóficas cristãs, sobretudo em São Paulo e Santo Agostinho, e posteriormente em São Tomás de Aquino e Duns Scotus, a faculdade da Vontade é descoberta, originalmente fundada nas experiências da conversão religiosa, e sua orientação para o futuro é garantida pela nova maneira a partir da qual os acontecimentos são interpretados, segundo o estabelecimento de um calendário cuja concepção temporal é retilínea (a via recta, segundo Santo Agostinho) e contempla Jesus Cristo como o iniciador de um novus ordo seclorum. Com o advento da Era Moderna, e apesar das ob- 
jeções apresentadas pelos filósofos em relação à faculdade da Vontade (Hobbes, Espinoza, Shopenhauer) - a negação de sua existência efetiva da idéia de liberdade, que lhe é subjacente, e da idéia de contingência - a Vontade é elevada a um plano de importância considerável, sobretudo graças à tão disseminada noção de progresso que, por sua vez, termina por se constituir num projeto da humanidade, tendo Hegel como seu principal fomentador. E a referência feita por Arendt aos maiores expoentes do idealismo alemão - Nietzsche e Heidegger -, possui uma conotação ilustrativa e uma demonstração de ineficácia de tais pensamentos para aquilo que parece ostensivamente ser central em seu pensamento inquieto, marcado pela tensão da criação do novo e da redenção do homem por ele mesmo: a liberdade e seu exercício, que é manifestado na ação. Por fim, ousamos discorrer sobre alguns aspectos do pensamento da autora que nos pareceram importantes, ocasião em que chamamos a atenção para a correlação lógica entre as seguintes noções: ação, liberdade, natalidade, mortalidade e princípio de causalidade.

Abstract: This paper aims of this to describe, from Hannah Arendt's point of view the theoretical and historical route that provide the emergence of one at the three faculties of the spirit: the faculty of the will or want. Drawing initially on ancient Greece, the paper also deals with contributions of classic, mediavel and modern thinkers. In a retrospective approach Arendt examines the perception and installation process of the faculty of the will, by correlating it with the advent and consolidation of the linear conception of time, essencially from christian origins, against the background of cyclical conception of time, from Greek origins. It also reflects about the clash between the faculties of will and thinking, by following the controversy between Saint Tomas Aquino and Duns Scotus about the subject. Finally, the paper links the faculty of the will to the idea of freedom which is rationale of human condition.

Key-words: The faculty of will, the faculty of thinking, the freedom. 


\section{REFERÊNCIAS}

ARENDT, Hannah. Entre o passado e o futuro. São Paulo: Perspectiva, 1972.

A vida do espírito: o pensar, o querer, o julgar. Rio de Janeiro: Reluma Dumará, 1993.

A condição humana. Rio de Janeiro: Forense Universitária, 1997. 